\title{
Optimasi Pemilihan Barang Dagangan bagi Pedagang Keliling dengan Algoritma Genetika
}

\author{
Iryanto $^{1}$, Eka Ismantohadi ${ }^{2}$ \\ ${ }^{1,2}$ Teknik Informatika Politeknik Negeri Indramayu, Jl. Raya Lohbener Lama No. 08 Indramayu 45252 \\ E-mail : iryanto@polindra.ac.id ${ }^{1}$,eka@polindra.ac.id ${ }^{2}$
}

\begin{abstract}
Abstrak
Adanya kendala meningkatkan tingkat kesulitan dalam melakukan pemilihan barang, tidak terkecuali bagi seorang pedagang keliling. Tentunya seorang pedagang ingin mengoptimalkan keuntungan yang diperolehnya. Namun keterbatasan tempat dan modal menjadikan pedagang tersebut memerlukan strategi khusus dalam proses pemilihan barang yang dibeli dan dijajakannya. Terlebih lagi suatu barang dagangan memiliki peluang yang berbeda untuk terjual sehari-harinya. Hal tersebut semakin menambah kerumitan pemilihan tersebut. Dalam artikel ini, masalah tersebut diselesaikan dengan menggunakan algoritma genetika. Hasil percobaan dan solusi analitik menunjukkan kesesuaian yang baik. Percobaan dengan $\mathrm{N}$-jenis barang juga dipaparkan dalam artikel ini.
\end{abstract}

Kata Kunci: Algoritma Genetika, Knapsack Problem, Optimasi Pemilihan Barang

\begin{abstract}
Existence of constraints increases difficulty in choosing the right goods for a seller. Indeed, the seller wants to optimize the profit gained. Due to limitation of capital and maximum capacity, the seller needs a certain strategy to do the selection. Moreover the fact that each goods has its own probability to sell makes the problem becomes more complex. In this paper, the problem is solved using genetic algorithm. The result of simulation is in a good agreement with analytical solution. The simulation of $N$-goods selection is also given in the paper.
\end{abstract}

Keywords: Genetic Algorithm, Knapsack Problem, Optimization of goods selection

\section{PENDAHULUAN}

Pemilihan suatu barang dapat menjadi sulit ketika melibatkan batasan atau kendala tertentu. Misalnya, pemilihan barang dagangan bagi seorang pedagang keliling. Tentunya seorang pedagang ingin mengoptimalkan keuntungan yang diperolehnya. Namun keterbatasan tempat dan modal menjadikan pedagang tersebut memerlukan strategi khusus dalam proses pemilihan barang yang dibeli dan dijajakannya. Terlebih lagi suatu barang dagangan memiliki peluang yang berbeda untuk terjual sehari-harinya. Hal ini semakin menambah kerumitan pemilihan tersebut.

Permasalahan tersebut dikenal dengan istilah Knapsack problem. Dari berbagai literatur Knapsack problem dapat dimaknai sebagai masalah optimasi pemilihan barang yang memiliki nilai dan bobot dengan kendala bobot (kapasitas) maksimum dari tempat penampung barang-barang tersebut. Masalah tersebut erat kaitannya dengan kehidupan sehari-hari tidak terkecuali bagi para pedagang keliling.

Dalam bidang optimasi pemilihan barang, proses pemilihan dilakukan sampai mendapatkan hasil (solusi) terbaik dari semua kemungkinan solusi yang ada. Penelitian dalam bidang ini telah banyak dikaji di berbagai literatur. Beberapa penelitian terkait dalam bidang kajian tersebut adalah :

- Penggunaan algoritma genetika untuk optimasi pemilihan buah kemasan kotak dikaji secara rinci di [7]. Dalam hal ini optimasi keuntungan mempertimbangkan tingkat kebutuhan pasar dan keawetan buah tersebut dengan kendala total berat buah dan volum kotak. Hasil simulasi menujukkan bahwa jumlah populasi berperan penting dalam perolehan fitness terbaik.

- Pemaparan perbandingan dari berbagai proses/metode mutasi algoritma genetika dalam penyelesaian 0/1 Knapsack problem oleh Hasan, dkk dibahas di [3]. Dari 50 kali percobaan yang dilakukan proses mutasi dengan inversi menghasilkan hasil dengan rata-rata tertinggi meski perbedaan performa secara umum tidak terlalu berbeda dibandingkan metode mutasi lainnya yang dipaparkan dalam artikel tersebut. Selain itu, representasi biner adalah cara terbaik untuk merepresentasikan Knapsack problem.

- Penelitian penataan letak barang 3D pada kontainer dengan menggunakan algoritma genetika dikaji secara rinci di [1]. Dalam 
penelitian ini, barang-barang tersebut berbentuk balok dan diletakkan hanya secara menyamping dengan dipisahkan berdasarkan tujuan, berat, volum dan jenis barang. Penelitian ini menghasilkan hasil yang menjanjikan.

- Implementasi algoritma genetika untuk optimasi persediaan barang dalam produksi jilbab di suatu perusahaan dipaparkan di [6]. Dalam artikel ini, nilai fitness ditentukan dengan meminimumkan biaya yang dibutuhkan selama proses produksi.

- Penggunaan algoritma genetika untuk menyelesaikan Knapsack problem juga dipaparkan di [8]. Dalam artikel ini fungsi objektif yang digunakan menyatakan optimasi total berat barang dengan kendala kapasitas maksimum dari tempat yang disediakan.

Dari pemaparan di atas, dapat dikatakan bahwa metode algoritma genetika baik digunakan untuk menyelesaikan Knapsack problem. Secara spesifik, dalam penelitian ini algoritma genetika tersebut diimplementasikan untuk menyelesaikan masalah pemilihan barang dagangan bagi pedagang keliling. Sehingga penelitian ini bertujuan untuk mengoptimalkan pemilihan barang dengan fungsi fitness dan kendala tertentu.

Adapun fungsi fitness dalam masalah ini adalah memaksimumkan keuntungan dengan mempertimbangkan nilai peluang suatu barang laku pada hari tertentu. Secara praktis nilai tersebut diperoleh dari riwayat penjualan atau dapat dilihat sebagai kecenderungan rasio antara jumlah barang yang laku terhadap jumlah total barang pada saat awal sebelum dijual.

Dalam penelitian ini kendala yang digunakan tidak hanya total bobot (berat) melainkan juga total biaya. Kedua kendala tersebut secara berurutan tidak boleh melebihi kapasitas maksimum tempat (gerobak) dan modal maksimum yang dimiliki pedagang setiap harinya.

Merujuk hasil penelitian yang disajikan di [3], algoritma genetika yang digunakan adalah algoritma genetika biner dengan proses mutasi inversi. Sedangkan dari referensi [7], nantinya akan digunakan jumlah populasi yang cukup besar dalam proses pencarian solusi dengan algoritma genetika tersebut.

Pemaparan mengenai algoritma genetika akan disajikan di Bab II. Proses implementasi dan perancangan sistem penyelesaian masalah tersebut akan dibahas lebih jauh di Bab III. Fungsi fitness dan kendala juga tersaji di bab tersebut. Hasil-hasil komputasi numerik akan diberikan di Bab IV. Penyajian ditutup dengan kesimpulan dan saran penelitian.

\section{ALGORITMA GENETIKA}

Algoritma genetika yang berkembang di saat sekarang dilatarbelakangi oleh penelitian yang dilakukan di Universitas Michigan yang dipimpin oleh John Holland di akhir tahun 1960an dan awal tahun 1970an [5]. Namun penggunaan algoritma genetika telah ada sejak awal tahun 1950an untuk simulasi masalahmasalah dalam bidang biologi [2].

Terinspirasi dari proses teori evolusi Darwin, algoritma genetika berkembang menjadi algortima komputasi untuk menyelesaikan masalah dengan prosesproses alamiah seperti proses reduksi, crossover, dan mutasi. Algoritma ini juga dikenal dengan istilah program evolusi [5] yaitu algoritma probabilistk yang mempertahankan individu-individu terbaik pada setiap generasinya.

Pada prakteknya nilai pobabilistik tersebut tercermin pada penggunaan bilangan acak. Nilai tersebut membuat solusi optimum global menjadi tidak pasti pula sehingga perancangan fungsi fitness dan pengaturan nilai parameter menjadi hal yang sangat diperlukan.

Adapun proses-proses pada algoritma genetika dalam menyelesaikan masalah optimasi dapat dinyatakan sebagai berikut (lihat [5] untuk lebih jelasnya) :

1. Representasi solusi yang merupakan pengkodean setiap individu

2. Pembangkitan populasi awal

3. Fungsi evaluasi yang dibuat berdasarkan masalah riil

4. Proses regenerasi (proses seleksi, crossover, dan mutasi)

\section{IMPLEMENTASI DAN PERANCANGAN}

Pada bab sebelumnya telah dijelaskan mengenai algoritma genetika berikut dengan rangkaian prosesnya. Pada bab ini hal-hal tersebut akan diimplementasikan untuk menyelesaikan masalah yang ada.

\subsection{Representasi Solusi}

\section{- Representasi Barang}

Dalam hal ini barang direpresentasikan ke dalam empat buah array satu dimensi yaitu array peluang (menyatakan peluang barang tersebut terjual di hari tertentu), array bobot (menyatakan berat dari masing-masing barang), array biaya (menyatakan harga beli masing-masing barang), dan array keuntungan (menyatakan besarnya keuntungan tiap barang). Sehingga entri/isi dari array-array tersebut adalah nilai-nilai yang bersesuaian dengan keadaan barang yang sebenarnya seperti yang tersaji dalam Tabel 1.

Tabel 1 Daftar Barang

\begin{tabular}{|c|c|c|c|c|}
\hline Barang & Peluang & Bobot & Biaya & Keuntungan \\
\hline 1 & 0,6 & 3 & 5.000 & 500 \\
\hline 2 & 0,7 & 5 & 7.000 & 750 \\
\hline 3 & 0,4 & 6 & 6.500 & 600 \\
\hline 4 & 0,3 & 7 & 4.000 & 250 \\
\hline 5 & 0,25 & 2 & 7.500 & 400 \\
\hline 6 & 0,5 & 5 & 8.000 & 600 \\
\hline 7 & 0,8 & 5 & 9.000 & 900 \\
\hline 8 & 0,9 & 4 & 4.500 & 250 \\
\hline 9 & 0,65 & 7 & 5.500 & 500 \\
\hline
\end{tabular}

\section{- Kendala}

Dalam masalah ini terdapat dua buah kendala yaitu berat total tidak boleh melebihi kapasitas 
maksimum dan modal. Dalam hal ini jumlah total biaya pembelian barang tidak boleh melebihi batas modal yang dimiliki oleh pedagang tersebut.

\section{- Pengkodean Kromosom}

Dalam algoritma genetika, kromosom yang tersusun atas gen-gen merepresentasikan calon solusi dari permasalahan yang ada [12].

Pengkodean kromosom dinyatakan dalam array biner dua dimensi dengan jumlah baris sesuai dengan banyaknya populasi awal dan jumlah kolom sesuai dengan banyaknya barang yang akan dioptimasikan pemilihannya. Masing-masing gen dalam kromosom tersebut menyimpan informasiinformasi seperti pada poin representasi barang.

\subsection{Pembangkitan Populasi Awal}

Pembangkitan populasi awal dimulai dengan membangkitkan kromosom secara acak sebanyak jumlah populasi awal yang ditentukan.

\subsection{Fungsi Fitness}

Fungi fitness menyatakan tingkat kebugaran suatu kromosom. Fungsi ini digunakan untuk mengukur kelayakan suatu kromosom untuk dipertahankan [12].

Adapun fungsi fitness pada penelitian ini adalah fungsi yang memaksimumkan keuntungan dengan nilai peluang terjual dan kendala yang disebutkan pada poin pertama. Suatu kromosom dihitung nilai total keuntungan, biaya, dan beratnya. Kromosom dengan nilai keuntungan terbesar itulah yang diambil namun dengan total biaya dan berat tidak melebihi kendala. Jika total biaya atau berat melebihi kendala maka nilai keuntungan kromosom tersebut diatur menjadi nol.

$$
\begin{aligned}
& f i t(i)=\sum_{k=1}^{\text {Pkrom }} \text { keuntungan }_{k} * \text { peluang }_{k} \\
& \text { fobj }=\operatorname{maks}_{i \in N p} \text { fit }(i)
\end{aligned}
$$

Dengan $N p$ menyatakan jumlah populasi dan Pkrom panjang kromosom dengan kendala:

$$
\sum_{k=1}^{\text {Pkrom }} \text { bobot }_{k} \leq w_{-} \text {maks \& } \sum_{k=1}^{\text {Pkrom }} \text { biaya }_{k} \leq \text { modal }
$$

\subsection{Proses Regenerasi}

\section{- Proses Seleksi}

Dalam penelitian ini proses seleksi menggunakan roulette wheel. Prinsip dari metode seleksi ini adalah setiap segmen roulette ditempati oleh masing-masing kromosom/individu yang nantinya akan digunakan sebagai orang tua (parent) jika terpilih. Besaran segmen roulette sesuai dengan rasio nilai fitness tiap individu dengan total nilai fitness [4]. Semakin besar segmen roulette tentunya peluang individu tersebut terpilih juga semakin besar. Selain itu, pada proses seleksi ini juga digunakan juga elitilism untuk mempertahankan nilai fitness terbaik suatu generasi agar tidak turun di generasi selanjutnya [9]. Dalam implementasinya, elitilism tersebut dilakukan dengan menyalin kromosom/individu dengan fitness terbaik tersebut sebanyak yang diinginkan.
Penentuan individu/kromosom dengan fitness terbaik dengan melakukan pengurutan nilai fitness. Adapun proses seleksi dengan roulette wheel dapat dinyatakan sebagai berikut:

$>$ Menghitung fitness tiap individu

$$
f i t(i)=\sum_{k=1}^{\text {Pkrom }} \text { keuntungan }_{k} * \text { peluang }_{k}
$$

$>$ Menghitung total nilai fitness untuk populasi

$$
\text { Fobj }=\sum_{i=1}^{N p} f i t(i)
$$

$>$ Menghitung fitness relatif setiap kromosom

$$
P(i)=\frac{f i t(i)}{F o b j}, i=1,2,3, \ldots, N p
$$

Menghitung fitness kumulatif setiap kromosom

$$
Q(i)=\sum_{j=1}^{i} P(j), i=1,2,3, \ldots, N p
$$

\section{- Proses Crossover}

Proses crossover ini bertujuan untuk menghasilkan individu/kromosom baru dari dua individu terpilih yang nantinya dijadikan sebagai orang tua/parent. Banyaknya jumlah orang tua tersebut ditentukan oleh parameter Pc (peluang crossover). Semakin besar nilai dari parameter Pc tersebut artinya akan semakin banyak pula orang tua yang terpilih yang nantinya akan mempengaruhi tingkat kevariatifan populasi individu tersebut.

Lebih lanjut, proses crossover yang digunakan adalah two-point crossover. Metode ini salah satu dari metode crossover yang paling sederhana namun banyak digunakan [10]. Rincian dari proses tersebut dapat dilihat di referensi tersebut. Namun demi kejelasan proses, berikut adalah langkahlangkah dalam melakukan proses two-point crossover :

$>$ Menentukan orang tua/parent crossover dengan cara membangkitkan bilangan acak $r=[0,1]$ dan $r \leq P c$.

$>$ Menentukan batas-batas crossover dengan cara membangkitkan bilangan acak r1,r2 = [1,PKrom $]$, dengan PKrom menyatakan panjang kromosom.

$>$ Misalkan $r 1<r 2$, selanjutnya tukar gengen dari parent pertama dengan parent kedua pada indeks $i \in[r 1, r 2]$

$>$ Misalkan diberikan dua buah parent dengan panjang kromosom sembilan, parent 1 dan parent 2 , dan $r 1=3, r 2=7$ Parent1

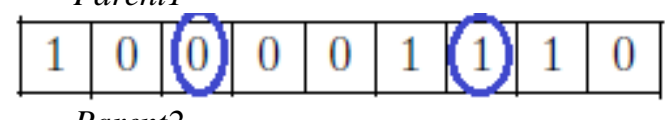
Parent2

\begin{tabular}{|l|l|l|l|l|l|l|l|l|}
\hline 1 & 0 & $(1)$ & 1 & 0 & 0 & 0 & 0 & 0 \\
\hline
\end{tabular}


Sehingga hasil crossover dari dua parent tersebut adalah

Anak1

\begin{tabular}{|l|l|l|l|l|l|l|l|l|}
\hline 1 & 0 & $(\mathbf{1})$ & $\mathbf{1}$ & $\mathbf{0}$ & $\mathbf{0}$ & $\mathbf{0}$ & 1 & 0 \\
\hline
\end{tabular}
\begin{tabular}{|l|l|l|l|l|l|l|l|l|}
\hline 1 & 0 & $\mathbf{0}$ & $\mathbf{0}$ & $\mathbf{0}$ & $\mathbf{1}$ & $\mathbf{1}$ & 0 & 0 \\
\hline
\end{tabular}

\section{- Proses Mutasi}

Proses mutasi ini dilakukan dengan cara menginverskan nilai dari gen. Dalam implementasinya, proses ini dilakukan dengan mengubah nilai gen (allele) 1 menjadi 0 dan 0 menjadi 1 [3]. Layaknya proses crossover, banyaknya gen yang mengalami mutasi dibatasi oleh suatu parameter tertentu. Dalam hal ini, parameter tersebut adalah Pm. Nilai Pm berpengaruh terhadap fitness yang dihasilkan. Nilai $\mathrm{Pm}$ yang besar dapat menyebabkan penurunan fitness suatu individu.

Adapun tahapan-tahapan proses tersebut adalah sebagai berikut:

> Menemtukan orang tua/parent mutasi dengan cara membangkitkan bilangan acak $r=[0,1]$ dan $r \leq P m$.

$>$ Menginverskan nilai gen ke $r r$ pada suatu kromosom dengan cara membangkitkan bilangan acak $r r=[1, P$ Krom $]$, dengan PKrom menyatakan panjang kromosom.

$>$ Misalkan diberikan parent dengan panjang kromosom sembilan dan nilai tiap gen sebagai berikut

\begin{tabular}{|l|l|l|l|l|l|l|l|l|}
\hline 1 & 0 & 1 & 1 & 0 & 0 & 0 & 0 & 0 \\
\hline
\end{tabular}

Bilangan acak $r r=6$ sehingga diperoleh hasil mutasi

\begin{tabular}{|l|l|l|l|l|l|l|l|l|}
\hline 1 & 0 & 1 & 1 & 0 & $\mathbf{1}$ & 0 & 0 & 0 \\
\hline
\end{tabular}

\subsection{Algoritma}

Berikut adalah algoritma yang digunakan untuk menyelesaikan permasalahan yang ada

1. Inisialisasi parameter-parameter simulasi

2. Inisialisasi populasi awal secara acak

3. Hitung nilai fungsi objektif, fitness berat (weight), dan biaya

4. Tetapkan $f o b j=0$ jika kendala tidak terpenuhi

5. Pilih calon induk crossover dan mutasi

6. Lakukan proses crossover

7. Lakukan proses mutasi

8. Tetapkan kromosom-kromosom baru dalam populasi tersebut

9. Ulangi langkah $3-8$ sampai batas evolusi maksimum

\section{HASIL DAN PEMBAHASAN}

Validasi program/koding yang digunakan dilakukan dengan cara membandingkan hasil keluaran program dengan solusi analitik Knapsack problem. Dalam hal ini percobaan dilakukan dengan data yang tertera dalam Tabel 1. Percobaan pertama dilakukan untuk lima jenis barang pertama saja dan percobaan berikutnya semua data dalam Tabel 1 digunakan. Adapun solusi analitik diperoleh dari perhitungan manual dengan membandingkan nilai fitness untuk semua kemungkinan solusi. Misalnya, untuk kasus lima jenis barang akan terdapat $2^{5}=32$ calon solusi sedangkan untuk sembilan jenis barang akan terdapat $2^{9}=512$ kemungkinan solusi. Percobaan lainnya dilakukan untuk $\mathrm{N}$-jenis barang yang cukup banyak. Pada percobaan ini waktu simulasi juga akan diamati.

\subsection{Validasi Program}

Percobaan dijalankan dengan parameter-parameter algoritma genetika sebagai berikut:

- $\quad$ Peluang mutasi $\mathrm{Pm}=0.05$

- $\quad$ Peluang crossover $\mathrm{Pc}=0.8$

- Banyaknya populasi awal $\mathrm{Np}=15$

- $\quad$ Elitilism = 10

- Evolusi maksimum $=100$

- $\quad$ Modal $=25.000$

- $\quad$ Berat maksimum W_maks $=19$

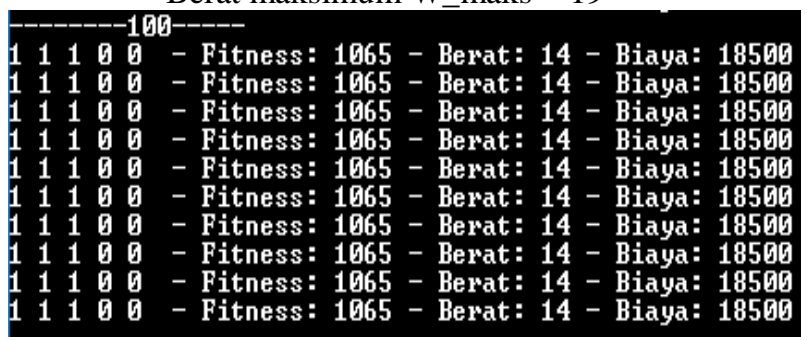

Gambar 1 Hasil Validasi 5 Jenis Barang

Berdasarkan Gambar 1 nilai fitness terbaik bernilai 1065 dengan total berat 14 dan total biaya 18.500 dengan rincian barang yang terpilih adalah barang pertama, kedua, dan ketiga. Hasil perhitungan analitik nilai fitness juga bernilai 18.500 dengan kromosom yang sama.

Percobaan selanjutnya menggunakan sembilan jenis barang dengan elitilism 90 dan banyaknya populasi 100 , elitilism 25 dan banyaknya populasi 30, berat maksimum 35, dan modal 65.000. Parameter lainnya sama dengan percobaan sebelumnya.

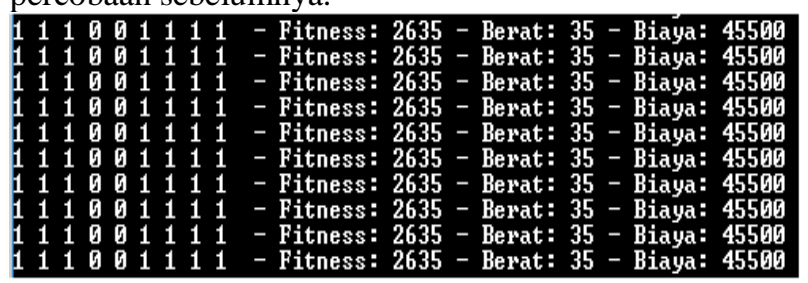

Gambar 2 Hasil Validasi 9 Jenis Barang

Hasil perhitungan analitik diperoleh nilai fitness terbaik sebesar 2635 dengan rincian barang yang terpilih adalah barang pertama, kedua, ketiga, keenam, ketujuh, kedelapan, dan kesembilan. Baik percobaan dengan banyaknya populasi 100 maupun 30 juga sama-sama menghasilkan nilai fitness terbesar senilai 2635 dengan rincian keluaran program seperti yang disajikan di 
Gambar 2. Namun dari 11 kali menjalankan program hasilnya berbeda-beda. Nilai rata-rata percobaan dengan 100 populasi sebesar 2.586 sedangkan dengan 30 populasi sebesar 2533 .

Dari dua hasil validasi tersebut dapat dikatakan bahwa program tersebut menghasilkan keluaran yang masuk akal dan baik sehingga program yang ada dapat digunakan untuk menyelesaikan masalah yang ada.

\subsection{Percobaan untuk N Jenis Barang}

Dalam hal ini diperlukan pengaturan memori untuk memfasilitasi percobaan tersebut. Di sini alokasi memori dilakukan secara dinamis, dynamic allocation memory, lihat [11] untuk lebih jelasnya. Sebagai contohnya percobaan dilakukan dengan 200 jenis barang dan 250 populasi awal, elitilisim 225, bobot maksimum 1000, modal 1.300 .000 serta nilai parameter algoritma genetika lainnya sama dengan nilai parameter yang digunakan di Subbab 4.1.

Nilai masing-masing array peluang, bobot, biaya, dan keuntungan dibangkitkan secara acak memenuhi

$$
\begin{gathered}
r(i)=\operatorname{random}[0,1] \\
\text { peluang }(i)=r(i) \\
\operatorname{bobot}(i)=r(i) * 10 \\
\text { keuntungan }(i)=r(i) * 1.000 \\
\text { biaya }(i)=r(i) * 10.000
\end{gathered}
$$

Dari 11 kali menjalankan program, diperoleh hasil fitness terbaik sebesar 73.149 dengan rincian kromosom seperti pada Gambar 3. Adapun nilai rata-rata fitness dari 11 kali menjalankan program tersebut adalah 67.795,27.

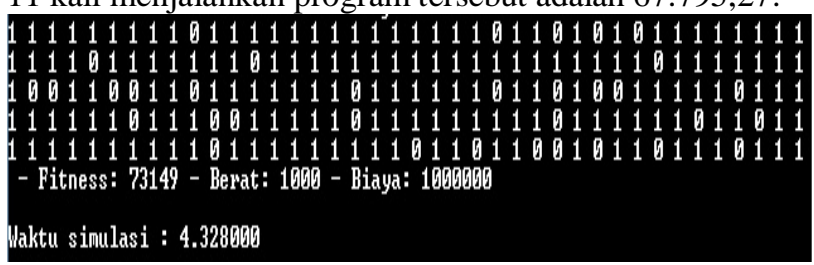

Gambar 3 Hasil N-Jenis Barang

Selain itu, waktu simulasi menujukkan perbedaan yang signifikan. Dapat dilihat pada Gambar 3 waktu simulasi percobaan tersebut adalah 4,328 detik sedangkan waktu simulasi untuk percobaan dengan 100 populasi dengan 5 dan 9 jenis barang secara berturutturut bernilai 0,062 detik dan 0,093 detik. Hal ini menunjukkan bahwa banyaknya populasi dan panjang kromosom berpengaruh terhadap waktu komputasi.

\section{PENUTUP}

\section{Kesimpulan}

Penyelesaian masalah pemilihan barang dagangan bagi pedagang keliling telah dipaparkan dengan lengkap. Untuk pemilihan barang dengan data seperti pada Tabel 1 , barang yang terpilih adalah barang pertama, kedua, ketiga, keenam, ketujuh, kedelapan, dan kesembilan dengan nilai fitness sebesar 2635. Hasil percobaan dengan algoritma genetika tersebut menunjukkan kesesuaian yang baik dengan solusi analitik. Pada percobaan $\mathrm{N}$-jenis barang diperoleh hasil fitness terbaik sebesar 73.149 dengan nilai rata-rata fitness sebesar 67.795,27. Selain itu pada percobaan ini terjadi peningkatan waktu komputasi yang signifikan.

\section{Saran}

Saran yang dapat penulis sampaikan adalah verifikasi hasil pada percobaan $\mathrm{N}$-jenis barang, misalnya dengan melakukan studi kasus tertentu. Saran lainnya adalah paralelisasi program untuk menurunkan waktu simulasi terutama untuk kasus pemilihan $\mathrm{N}$-jenis barang.

\section{VI.DAFTAR PUSTAKA}

[1] Farosanti, Lafnidita. "Simulasi 3D optimasi penataan barang pada kontainer menggunakan Algoritma Genetika." Skripsi. Universitas Islam Negeri Maulana Malik Ibrahim, 2015.

[2] Goldberg, David E., and Robert Lingle. "Alleles, loci, and the traveling salesman problem." Proceedings of an International Conference on Genetic Algorithms and Their Applications, vol. 154. Lawrence Erlbaum, Hillsdale, NJ, 1985.

[3] Hasan, Basima Hani F., and Moutaz Saleh M. Saleh. "Evaluating the effectiveness of mutation operators on the behavior of genetic algorithms applied to non-deterministic polynomial problems." Informatica, 2011, vol. 35(4), pp. 513-519.

[4] Kumar, Rakesh. "Blending roulette wheel selection \& rank selection in genetic algorithms." International Journal of Machine Learning and Computing, 2012, vol. 2(4), pp. 365-370.

[5] Michalewicz, Zbigniew. "Genetic Algorithms+ Data Structures= Evolution Programs." Springer Berlin Heidelberg, 1996.

[6] Ramuna, Maretta Dwi Tika, and Wayan Firdaus Mahmudy. "Optimasi Persediaan Barang Dalam Produksi Jilbab Menggunakan Algoritma Genetika." DORO: Repository Jurnal Mahasiswa PTIIK Universitas Brawijaya, 2015, vol. 5(14), pp. $1-10$.

[7] Setemen, Komang. "Implementasi Algoritma Genetika Pada Knapsack Problem Untuk Optimasi Pemilihan Buah Kemasan Kotak." Seminar Nasional Aplikasi Teknologi Informasi (SNATI), 2010, pp. 21-25.

[8] Supriana, I. Wayan. "Optimalisasi Penyelesaian Knapsack Problem Dengan Algoritma Genetika." Lontar Komputer: Jurnal Ilmiah Teknologi Informasi, 2016, vol. 7(3), pp. 858-868.

[9] Dyer, DW. "Evolutionary Computation in Java: A Practical Guide to the Watchmaker Framework." 2008,http://watchmaker.uncommons.org/manual/ch03s0 6.html. Diakses 29 Januari 2017.

[10] Sastry, Kumara, David E. Goldberg, and Graham Kendall. "Genetic algorithms." Search methodologies. Springer US, 2014, pp. 93-117.

[11] Séméria, Luc, Koichi Sato, and Giovanni De Micheli. "Resolution of dynamic memory allocation and pointers for the behavioral synthesis form C." Proceedings of the conference on Design, automation and test in Europe. ACM, 2000, pp 312319.

[12] Mitchell, Melanie. "An introduction to genetic algorithms." MIT press, 1998. 